\title{
Facial Cellulitis of Dental Origin: Experiments from the University of Bouaké Health Centre (Cote d'Ivoire)
}

\author{
N'guessan Eric Kouassi Zegbeh1", Ogou Kevin Elie Digbeu1, Pornan Issa Jules Bérété1, \\ Faozo Landry Teti ${ }^{1}$, Angel Michael Goulé ${ }^{2}$, Grébéret Emmanuel Crezoit ${ }^{1}$

\footnotetext{
${ }^{1}$ Department of Stomatology and Maxillo-Facial Surgery of the University of Bouaké Health Centre, Bouaké, Cote d'Ivoire ${ }^{2}$ Department of Ophthalmology of the Bouaké University of Bouaké Health Centre, Bouaké, Cote d'Ivoire Email: *zndes@yahoo.fr
}

How to cite this paper: Zegbeh, N.E.K., Digbeu, O.K.E., Bérété, P.I.J., Teti, F.L., Goulé, A.M. and Crezoit, G.E. (2020) Facial Cellulitis of Dental Origin: Experiments from the University of Bouaké Health Centre (Cote d'Ivoire). Open Journal of Stomatology, 10, 97-105.

https://doi.org/10.4236/ojst.2020.105011

Received: April 5, 2020

Accepted: May 16, 2020

Published: May 19, 2020

Copyright $\odot 2020$ by author(s) and Scientific Research Publishing Inc. This work is licensed under the Creative Commons Attribution International License (CC BY 4.0).

http://creativecommons.org/licenses/by/4.0/

(c) (i) Open Access

\begin{abstract}
Context: Facial cellulitis of dental origin is relatively frequent and severe. Objective: The aim of this document to describe the epidemiological, clinical, therapeutic and evolutionary aspects of facial cellulitis of dental origin in Bouaké. Methodology: This was a retrospective and descriptive study carried out in the stomatology and maxillofacial surgery department of the University of Bouaké Health centre over a period of 19 months (January 2018 to October 2019). All patients with facial cellulitis of dental origin were included. The parameters studied were epidemiological, clinical, therapeutic and evolutionary. Results: 179 patients were collected (hospital prevalence of 20.79\%). The average age was 34 years (min 1-year-old and max 80 -year-old). The sex ratio was 1.18. Among the patients, some were craftsmen (31.28\%) and others were farmers $(21.79 \%)$. The favourable factors included the nonsteroidal anti-inflammatory $(77.65 \%)$ and traditional therapeutics (44.13\%). The average number of days before consultation was 13 days (min 1 day and max 75 days). There were 7 cases of chronic cellulitis (3.91\%) and 172 cases of acute cellulitis, including 107 (62.21\%) circumscribed cellulitis, 51 (29.65\%) diffused cellulitis, and $14(8.14 \%)$ necrotizing fasciitis. The causal lesion was tooth decay (96.09\%) and dental avulsion without antibiotherapy (3.91\%). Incision and drainage was made in 145 patients (81\%) necrosectomy surgery in 54 patients $(30.17 \%)$. The mortality rate was $13.96 \%$. Conclusion: Facial cellulitis of dental origin are clinically polymorphic with significant mortality prompting increased dental decay prevention actions.
\end{abstract}

\section{Keywords}

Cellulitis, Dental, Suppuration, Necrosis 


\section{Introduction}

Facial cellulitis of dental origin is an inflammation of the cellular adipose tissue located in the lodges surrounding the mandible and maxilla, developing from a dental infectious focus. It is a potentially serious and fatal condition [1] [2] [3]. These facial cellulitis of dental origin have circumscribed forms, diffused forms and diffuse forms called necrotizing fasciitis [4]. From a nosological point of view this classification of cellulitis mainly concerns French-speakers while English-speakers use the generic term "necrotizing fasciitis" to refer to all types of cellulitis [1]. The subject of facial cellulitis of dental origin has often been treated internationally and regionally [2] [5] [6] [7]. However, very few papers deal with the aforementioned French-speaking nosological characteristics. Bouaké is a city in the central west of Côte d'Ivoire, recovering from a military political crisis that lasted 10 years. Since the return to a normal social situation, the stomatology and maxillofacial surgery department of the hospital and university of Bouaké, has received numerous cases of facial cellulitis of dental origin. However, there is no recent local database published on this pathology. The objective of the study was to describe epidemiological, clinical, therapeutic and evolutionary aspects.

\section{Methodology}

This was a retrospective and descriptive study carried out in the stomatology and maxillofacial surgery department of the University of Bouaké Health centre from January 2018 to October 2019, a period of 19 months. All patients with facial cellulitis of dental origin were included. Patients with a face infection not involving facial fat pad and/or non-dental etiology were not included in the study. All incomplete medical records were excluded. The parameters studied were epidemiological (sex, age, place of residence, occupation, antecedent), clinical (consultation delays, general condition, causal tooth, stage and location of cellulite), paraclinic (bacteriology, radiology) therapeutic (medical and surgical) and evolutionary. Depending on the French nosological design of facial cellulite of dental origin, there are diagnostic criteria characterizing the different evolutionary forms. Also, in the circumscribed cellulitis, infection of cellular adipose tissue is located in the vicinity of the area where the causal tooth is situated; inside a facial fat pad region. From this location, the infection can spread to nearby facial fat pad region or even extra facial areas. When this spread of infection and inflammation does not involve extensive necrosis, it defines the entity called "diffused cellulitis". In contrast to circumscribed cellulitis, the diffuse inflammation of cellular adipose tissue, with no tendency to limit and complicated by extensive necrosis of inflamed tissues, is described as "necrotizing fasciitis". Data collection and processing was carried out using SPSS 20.0 software. As for inputting tables and graphs, Word and Excel 2010 software were used.

\section{Results}

During this study period, 179 patients collected from 861 patients who had con- 
sulted in the odontostomatology and maxillofacial surgery department, representing a hospital prevalence rate of $20.79 \%$. The average age of patients in this study was 34 years with minimal age is 1 -year-old and maximun age is 80 -year-old. The 16 to 30 -year-old age group was 40.48 per cent (Figure 1). The sex ratio was 1.18 with 97 men and 82 women. Patients lived in the city of Bouaké in $55.9 \%$ of cases. The profession is represented in Table 1 . Nonsteroidal inflammatory drugs (NSAIDs) were used by 109 patients $(60.89 \%)$ and poor oral hygiene was observed in 170 patients $(94.97 \%)$ (Table 2 ). The consultation period was between 1 and 7 days in 92 cases (51.4\%), between 8 and 14 days in 25 cases (13.97\%), between 15 and 21 days in 47 cases (26.26\%) and more than 21 days in 15 cases (8.37\%). The number of days before consultation was 13 days with minimum 1 day and maximum 75 days. General condition was good in 138 patients (77.09\%) and impaired in 41 patients (22.91\%). Facial cellulitis of dental origin was acute in 172 cases $(96.09 \%)$ and chronic in 7 cases (3.91\%). Among acute cellulitis, $107(62.21 \%)$ was circumscribed cellulitis, 51 (29.65\%) was diffused cellulitis (Table 3 \& Table 4 ) and 14 (8.14\%) was necrotizing fasciitis (Figures $2-4)$. The 8 cases $(15.68 \%)$ of diffused cellulitis in the thoracic region had 6 parietal forms (75\%) and 2 mediastinitis (25\%). The causal lesion was tooth decay in 172 cases $(96.09 \%)$ and dental avulsion without antibiotherapy in 7 cases (3.91\%). For Facial cellulitis of dental origin studied, the causal tooth was mandibular in 162 cases (90.50\%). Thus, the second molar was identified in 3 cases $(1.85 \%)$, the first molar in 65 cases $(40.12 \%)$, the second molar in 59 cases (36.42\%) and wisdom tooth in 35 cases (21.60\%). The causal tooth was maxillary in 17 cases $(9.50 \%)$. Among them, was an incisor in 3 cases (17.65\%), a canine in 8 cases $(47.06 \%)$, a first premolar in 3 cases $(17.65 \%)$ and a second premolar in 3 cases $(17.65 \%)$. Facial X-rays were performed in 160 patients $(89.3 \%)$. The tomodensitometry was performed in 9 patients $(5.03 \%)$. The bacteriological study of pus was carried out in 77 cases (43.02\%). It revealed 30 cases $(38.96 \%)$ of Streptococcus Sp, 10 cases (12.99\%) of Staphylococcus aureus, 5 cases (6.49\%) of Pseudomonas aeruginosa and 7 cases (9.09\%) of Escherichia Coli. In 25 cases $(32.47 \%)$, the bacteriological examination did not identify a causal germ. For treatment, probabilistic antibiotherapy with ceftriaxone $50 \mathrm{mg} / \mathrm{kg} /$ day and metronidazole $30 \mathrm{mg} / \mathrm{kg} / \mathrm{day}$ was performed as usual in all cases. This antibiotherapy was then adapted to patients' antibiogram. All necrotizing fasciitis and 13 cases $(7.26 \%)$ among the diffused cellulitis were taken care of by the resuscitation service. All patients with necrotic cellulitis had a surgical necrosectomy causing a loss of substance whose budding was done with honey. Some of which was repaired by skin graft (13 cases) and for others by directed scarring (Table 5). All 160 patients (89.39\%) surgically treated benefited from a rehabilitation of the oral cavity including 153 dental avulsions (95.63\%) associated with Intra-alveolar curettage and 7 isolated intra-alveolar curettage (4.37\%). In 13 cases (7.26\%), surgical treatment consisted only of having a dental avulsion. Six other patients (3.35\%) left against medical advice and without receiving surgical 
treatment. The final results showed improvement in patient's condition for 148 cases $(82.68 \%)$. There were 25 cases $(13.96 \%)$ of death including 10 cases $(40 \%)$ of necrotizing fasciitis and 6 cases (24\%) of circumscribed cellulitis and 9 cases (36\%) of spread cellulite. Deaths were due to septic shock in 19 cases (76\%) and respiratory distress in 6 cases $(24 \%)$.

Table 1. Distribution according the occupation.

\begin{tabular}{ccc}
\hline Occupation & Frequency & Percentage \\
\hline craftsmen & 56 & $31.28 \%$ \\
Farmer & 39 & $21.79 \%$ \\
Merchant & 45 & $25.14 \%$ \\
Student & 19 & $10.61 \%$ \\
Teacher & 03 & $1.68 \%$ \\
Non-professional & 17 & $9.5 \%$ \\
Total & 179 & $100 \%$ \\
\hline
\end{tabular}

Table 2. Distribution according factors favouring.

\begin{tabular}{ccc}
\hline Favourable factors & Frequency & Percentage \\
\hline NSAIDs & 109 & $60.9 \%$ \\
Traditional therapy & 49 & $27.37 \%$ \\
NSAID + Traditional therapy & 30 & $16.75 \%$ \\
Pregnancy & 11 & $6.14 \%$ \\
Diabetes & 5 & $2.79 \%$ \\
HIV & 1 & $0.56 \%$ \\
Poor oral hygiene & 170 & $94.97 \%$ \\
\hline
\end{tabular}

Table 3. Distribution of circumscribed cellulite according to topography and anatomopathic form.

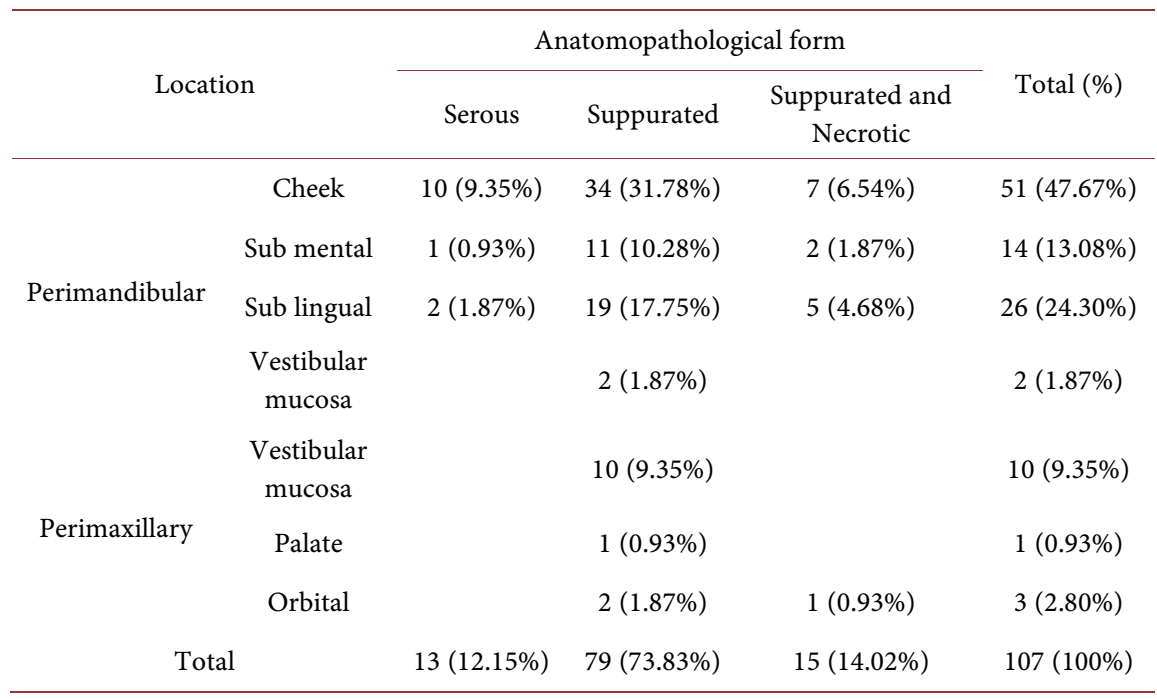


Table 4. Distribution of diffused cellulitis according topography and anatomopathological form.

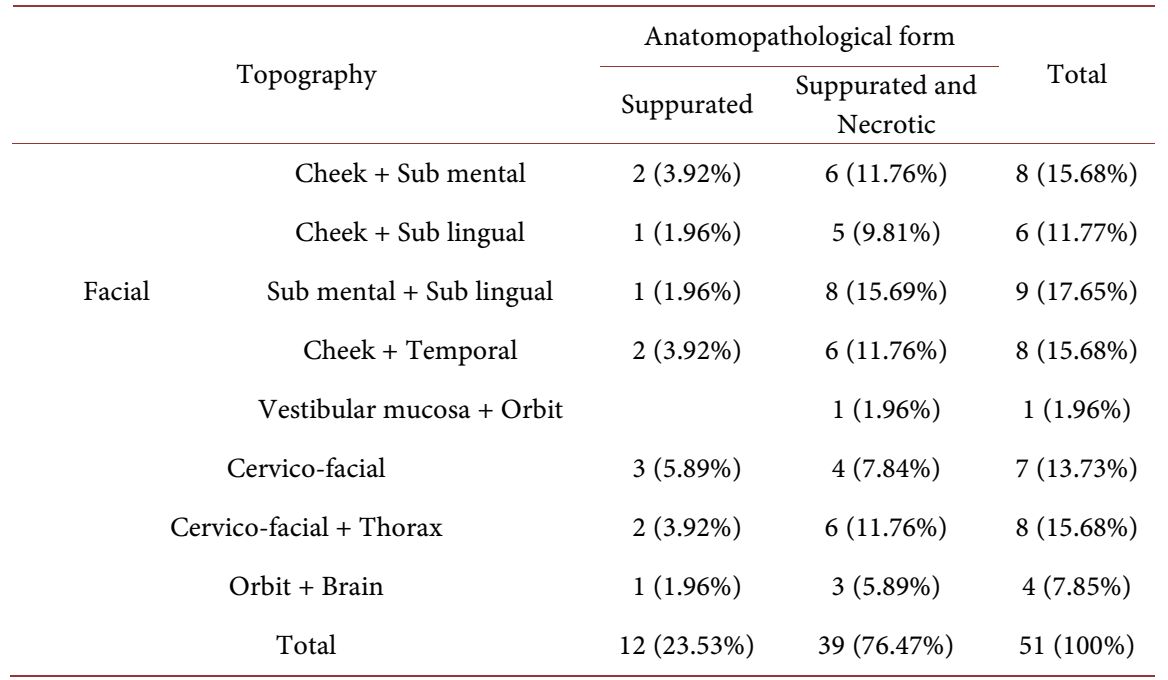

Table 5. Distribution according surgical procedure.

\begin{tabular}{ccc}
\hline Surgical procedure & Number & Percentage \\
\hline Only incision and drainage & 103 & $57.54 \%$ \\
incision and drainage + thoracic drainage & 2 & $1.12 \%$ \\
Incision and drainage + thoracotomy & 1 & $0.56 \%$ \\
Only Nécrosectomy & 10 & $5.59 \%$ \\
Incision and drainage + nécrosectomy & 31 & $17.32 \%$ \\
Nécrosectomy + skin graft & 5 & $2.79 \%$ \\
Ancision and drainage + nécrosectomy + skin graft & 8 & 4.47 \\
Total & 19 & $10.61 \%$ \\
\hline
\end{tabular}

50 years and more

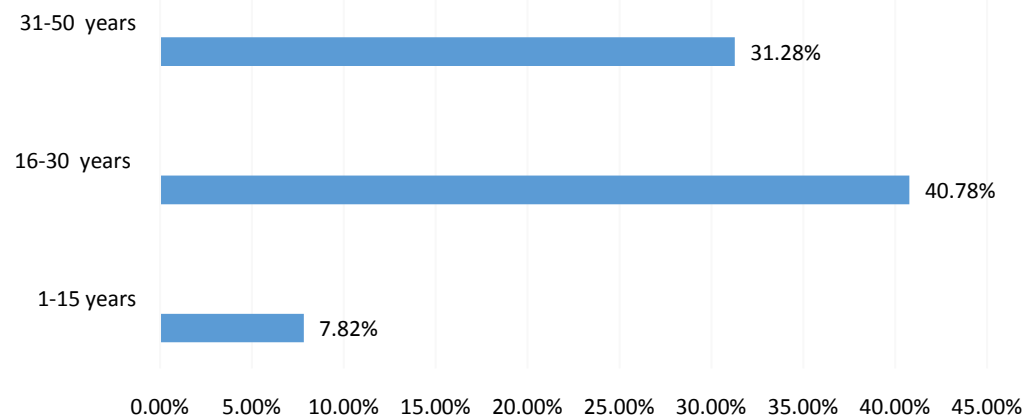

Figure 1. Distribution of patients by age group. 


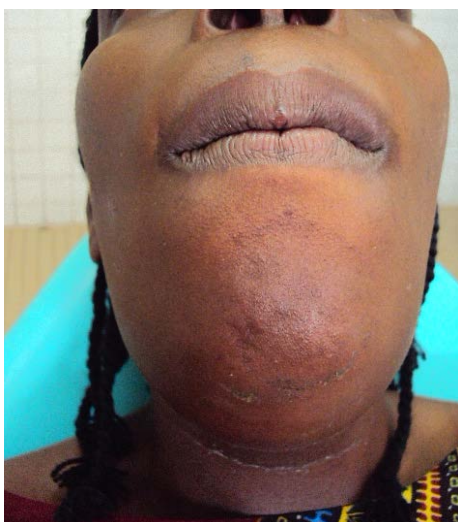

Figure 2. Submental circumscribed cellulitis.

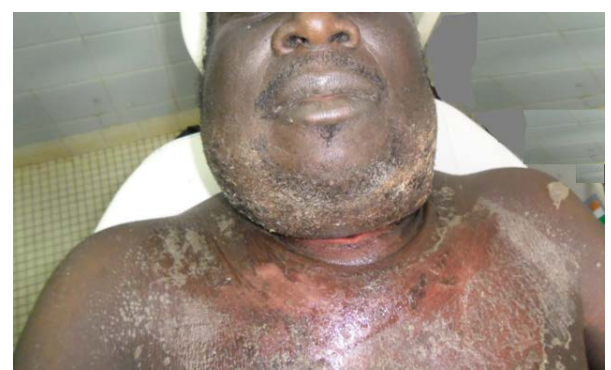

Figure 3. Bilateral cheek cellulitis of dental origin diffused in cervico-thoracic region.

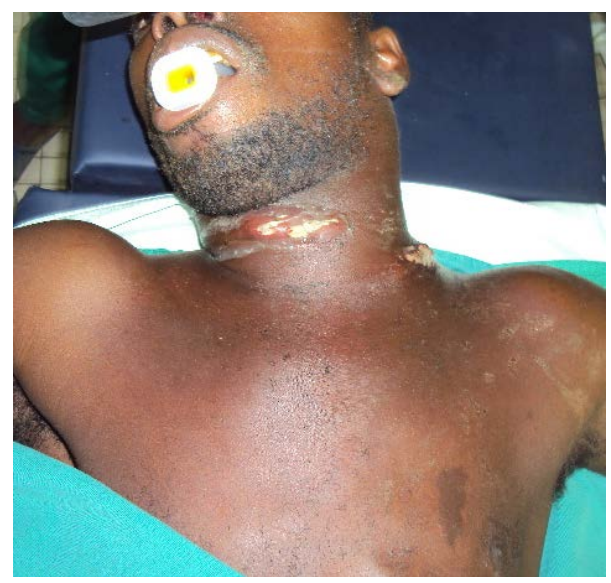

Figure 4. Cervico-facial necrotizing fasciitis of dental origin.

\section{Discussion}

The hospital prevalence rate of facial cellulitis of dental origin was relatively high (20.79\%). This trend is correlated with the fact that there has been an increase in cases of cervico-facial infections as a result of the economic crisis stemming from the last military conflict in the city of Bouaké. Indeed, in the absence of social security, many patients would prefer to be cared for by clandestine dental practitioners supposedly providing care at a lower cost. However, these practitioners have no accreditation and practice without any basic rules of antibiothe- 
rapy. For some patients, dentophobia is the main barrier to attending a hospital [8]. The study revealed a predominance of a young population (average age of 34 years), male (sex ratio of 1.18) and evolving in an unfavourable economic context (craftsmen in $31.28 \%$, farmers in $21.79 \%$ ). This population is the most active and probably the least concerned by the basics of oral hygiene. This trend is also observed in Zegbeh et al. [9]. The most important factors were: poor oral hygiene (94.97\%), NSAIDs (60.9\%) and Traditherapy (27.37\%). The implication of poor oral hygiene is almost omnipresent in the genesis of dental cellulitis [3]. As for the use of NSAIDs, they are widely used in developing countries because they provide relief dental pain at a lower cost, the distribution being carried out by street vendors. The consequence is the suppression of local immunity, allowing the spread of tooth infection to peripheral adipose tissues. Traditional therapy is an African feature that uses the form of infusion or cataplasm. It is based on a spiritual conception of the disease and tends to lengthen the therapeutic route. This explains the long period of time before consulting a doctor as observed in this study (13 days). In the Zegbeh et al. study, on thoracic diffusion of dental cellulitis, NSAIDs was observed in $88.23 \%$ of cases. This study made it possible to postulate on the factor promoting but also aggravating an additional NSAIDs on dental cellulitis [9]. Traditional therapeutic is a factor that has also been observed by Badou and N'gapeth Ethoundi, but at much lesser proportions [8] [10]. Molars were the most commonly observed infected teeth in our sample, especially the lower first molar (40.12\%). This could be explained by their posterior position which makes them more difficult to reach during dental brushing. The first molar, being the first permanent tooth to erupt, is believed to be the tooth that has been most exposed to bacteria for the longest time. This predominance of the first mandibular molars is also observed by Niang et al. [11]. The majority of circumscribed cellulitis of dental origin was suppurated (73.83\%) while diffused cellulitis was mostly suppurated and necrotic (76.47\%). This situation could be explained by that the fact that the presence of necrotic tissues could cause, through aponeurotic rupture, the passage of the infection from facial fat pad region to nearby facial fat pad region or even extra facial areas. Classically, the title "cellulitis", used by French-speaking clinicians, combines a necrosis of connective tissue and adipose tissue, but without the affected superficial fascias [12]. It is therefore likely that diffused cellulitis is actually an attenuated or intermediate form of necrotizing fasciitis. Surgical treatment consisted of surgical necrosectomy in 54 cases $(30.17 \%)$. This reveals the aggressive and mutilating tendency of surgery. This behavior is due to the potentially serious nature of the infection, especially in necrotizing fasciitis. As a result, symptoms are often late in relation to the actual level of necrotic tissue impairment [4]. However, despite combining antibiotherapy, surgery and resuscitation, the mortality rate is relatively high. This is directly attributable to the number of day before consultation, the severe forms and the limited technical platform for resuscitation. Badou et al. recorded $8.22 \%$ deaths from cervico-facial cellulitis and Sami Rouadi had a zero mortality rate [2] [10]. 


\section{Conclusion}

Facial cellulitis of dental origin at the Bouaké University Hospital mostly concerns male patients, young and dwelling in an unfavorable economic context. Topographic and evolutionary forms are polymorphic and of varying gravity. Treatment was based on antibiotic therapy, drainage incision and necrosectomy with sometimes considerable consequences on life, functional and aesthetic prognosis. Moreover, the conclusions of this study, can be considered partial. Indeed, it was carried out in a hospital, over a relatively short period of time and on a relatively small sample. This opens up the prospect of multi-center studies over longer durations and larger case samples. For now, the prevention of tooth decay remains the most effective and accessible weapon.

\section{Conflicts of Interest}

The authors declare no conflicts of interest regarding the publication of this paper.

\section{References}

[1] Bennani-Baïti, A.A., Benbouzid, A. and Essakalli-Hossyni, L. (2015) Les cellulites cervico-faciales: l'impact de l'utilisation des anti-inflammatoires non stéroïdiens. À propos de 70 cas. Annales françaises d'Oto-rhino-laryngologie et de Pathologie Cervico-faciale, 132, 169-173. https://doi.org/10.1016/j.aforl.2015.01.004

[2] Rouadi, S., Ouaissi, L., El Khiati, R., Abada, R., Mahtar, M., Roubal, M., et al. (2013) Les cellulites cervico-faciales à propos de 130 cas. Pan African Médical Journal, 14, Article 88. https://doi.org/10.11604/pamj.2013.14.88.1477

[3] Odzili, F.I., Guimbi, K.M., Boumandoki, P.J.C., Otiobanda, G.F., Ovoundard, M. and Ondzotto, G. (2014) 67 cas de cellulite cervico-faciale, pris en charge sous anesthésie locale au CHUB de Brazzaville. Revue de Stomatologie, de Chirurgie Maxillo-faciale et de Chirurgie Orale, 115, 349-352. https://doi.org/10.1016/j.revsto.2014.10.010

[4] Peron J,M. and Mangez, J.F. (2002) Cellulites et fistules d'origine dentaire. Encycl Méd Chir (Editions Scientifiques et Médicales Elsevier SAS, Paris, tous droits réservés), Stomatologie/Odontologie, 22-033-A-10, 14 p.

[5] Htiti, A., Hemmaoui, B., Kasouati, J., Dimou, M., Belyaman, L. and Kzadri, M. (2013) Facteurs predictifs de gravite des cellulites cervico-faciales diffuses d'origine dentaire: A propos de 78 cas. Journal Tunisien d'ORL et de Chirurgie Cervico-Faciale, 29, 31-35. https://doi.org/10.4314/jtdorl.v19i1.57887

[6] Bertolus, C.H. (2011) Cellulite cervico-faciale. Urgences 2011, Chapitre, 52.

[7] Togo, S., Yena, S., Ouattara, M., Saye, J., Sankare, I.B., et al. (2016) Cellulite nécrosante descendante infectieuse d'origine dentaire à diffusion mammaire: Analyse de deux cas. Revue Malienne d'Infectiologie et de Microbiologie, 7, 8-10.

[8] Ngapeth-Etoundi, M., Itoua, E.S.R., Obounou, A. and Alma, J.A. (2001) Etude clinique des complications infectieuses dentaires et peridentaires observees a l'Hopital Central de Yaounde-À propos de 161 cas. Tropical Dental Journal, 93, 5-10.

[9] Zegbeh, N.E.K., Koné-Kamaté, R., Boka, L., Traoré, I., Harding-Kaba, M.B., et al. (2017) Diffusion thoracique des cellulites péri-maxillaires. Afrique Biomedicale, 22 , 64-69. 
[10] Badou, K.E., Buraima, F., Yoda, M., Traore, K.E., Kouassi, Y.M., Tanon-Anoh, M.J., et al. (2014) Cellulites cervico-faciales au Centre Hospitalo-Universitaire de Yopougon (Abidjan-cote d'Ivoire). Revue internationale du Collège Odonto-Stomatologie Africain et de Chirurgie Maxillo-faciale, 21, 5-10.

[11] Niang, P.D.A., Tamba, B., Tamba-Fall, A., Dia-Tine, S., Ba, A. and Diop, R. (2011) Cellulites périmaxillaires: aspects étiologiques et considérations anatomo-cliniques. Médecine Buccale Chirurgie Buccale, 17, 261-266.

https://doi.org/10.1051/mbcb/2011137

[12] Gauzit, R. (2006) Infections cutanées graves: Définitions, caractéristiques cliniques et microbiologiques. Annales françaises d’anesthésie et de réanimation, 25, 967-970. https://doi.org/10.1016/j.annfar.2006.03.018 